\title{
Analysis of Remittance on Well-being of Households: A Case Study of Sindhupalchok District of Nepal
}

Ananta Raj Dahal (PhD Scholar)*

\begin{abstract}
Remittance is the backbone of Nepalese's economy in the present time. This study analyses the wellbeing of the remittance receptive household in the Melamchi Municipality of the Sindhupalchok District. Primary data were used as the main sources of information and secondary data were also used as supplementary sources. Primary data were collected by the direct personal interview through the semi-structural questionnaire survey of the sample area people who were selected by judgmental sampling method. Descriptive statistics has been used as the tools of data analysis of wellbeing of the remittance receptive households. Main destination of the employees of the sample area people is Malasia and Golf-country and they had used unorganized sectors as the sources of financing. Bank and money transfer had been used for the sources of money transfer in the sample area migrants. In the sample area people used, remittance has emerged as one of the major sources of income earning and they used that amount for their wellbeing. They increase their living standard through health facility, education facility and purchase of durable and comfortable goods. They invest for land and house purchase but not invest for the production as well as business. It has played a vital role in changing the lifestyle of the sample area people.
\end{abstract}

Key word: Well-being, remittance, receive, migrants \& employees.

\section{Introduction}

Remittance means the money amount sent by the peoples from the foreign country to their home country. Remittances play a significant role in the household consumption and economic development of the beneficiary country. Attractive increasing of the remittances may occur through different macro and microeconomic channels. Moreover, either remitted amount are oriented to consumption as well as investment, they ensre to

${ }^{\star}$ Mr. Dahal is a Lecturer at the Department of Economics, Patan Multiple Campus, TU, Lalitpur, Nepal.Email: anantadahal38@yahoo.com 
have direct behavior for economic expansion. At the microeconomic level, remittances help household dispute poverty and improve the income sharing in support of the poor (Nisar \& Tufail, 2013). By moderation of the credit and liquidity, constraints may lead to higher level of household consumption and investment. Remittances make available self-insurance to the beneficiary households in times of uncertainties, economic failure and natural disasters Khan (2009). Remittance income does not advantage just individual recipients, its settlement the local and countrywide economies in which they exist. Actually, the expenses acceptable by remittances has a multiplied consequence on local economies as funds subsequently spent create incomes for others and motivate economic motion normally. Further than such multiplier effect, there are other factors beneficial to economic expansion and strength.

Hoyos (2004) examined the consumption patterns of remittance-receiving households in Mexico. Tchantchane et. al. (2013) used the econometric model, Autoregressive Distributed Lag (ARDL) model to determine the relationship between remittance, education expenditure and investment on economic growth in the Philippines. Gaudel (2006) examined the impact of remittance in economic development of Nepal on a research "Remittance Income in Nepal: Need for Economic Development." Neupane (2011) analyzed the impact of remittances on Nepalese economy and found that remittance inflow and domestic consumption expenditure have positive relationship. Thapa and Acharya (2017) showed the evidence that the average budget share of the remittance recipient and non-recipient households shows a marginal difference in the expenditure share on different consumption goods (e.g., food and nonfood) and investment (e.g., health and education). Katuwal (2020) analyzed remittance and its impact on Nepalese economy

In the context of Nepal, remittance has emerged as one of the main sources of foreign currency in recent year. It has been an important foundation for family members remaining at home. Remittance plays a significant role in the Nepalese economy and it has been cleared that remittance sent by foreign employees is one of the most valuable tools for poverty mitigation. Furthermore, it would be highly advantageous to Nepal, where there is political inconsistency, natural calamities, low investment in entrepreneur activities and economic recession.

\section{Objectives}

The overall objectives of this study is to examine the effect of remittance on household population in Melamchi Municipality on Sindhupalchok district of Nepal. The specific 
objective of this study is to analyses the wellbeing of the people through the consumption pattern before and after the remittance.

\section{Data and Methodology}

Following number of stapes were followed to accomplish this study.

\section{Research Design}

Aim of this research has to analyze the effect of remittance on household welfare of the sample area people. In social science research, field work is the central and important methods for collecting the primary information. Secondary information also plays the supplementary role. This study is based on both primary and secondary data and has used descriptive statistics tool for data analysis.

\section{Sample Size and Data Collection}

There are 700 households in Melamchi Municipality-5, of Sindhupalchok district. Among them 60 representative household have been selected by judgmental sampling methods at least whose one family member is in foreign employment. Direct personal interview with family members who have been receiving remittance has been taken for the interview during the field survey through the semi-structure questionnaires.

\section{Results and Discussion}

\section{Situation of Foreign Employees in Different Countries}

In household survey it was found that Malaysia, Gulf countries, Japan. Korea, India is the main destination for foreign employment. Europe \& USA and other countries like Australia, Israel, and China etc. are chosen for study. The distribution of sampled migrant people on the basis of destination country is presented in the following table.

Table 1: Foreign employees in different country

\begin{tabular}{|l|c|c|}
\hline Migrated Countries & Number & Percent \\
\hline Malaysia & 13 & 21.67 \\
\hline Gulf Countries & 16 & 26.67 \\
\hline Japan & 8 & 13.33 \\
\hline Korea & 3 & 5.00 \\
\hline India & 3 & 5.00 \\
\hline
\end{tabular}




\begin{tabular}{|l|c|c|}
\hline Europe \$ USA & 9 & 15.00 \\
\hline Other Countries & 8 & 13.33 \\
\hline Total & $\mathbf{6 0}$ & $\mathbf{1 0 0 . 0 0}$ \\
\hline
\end{tabular}

Source: Field Survey, 2019

Table 1, expresses the major destination country for foreign employment in sample area. From the total employee migrant Gulf-countries 26.67 percent, Malaysia 21.67 percent, Japan 13.33 percent, Korea 5 percent, India 5 percent, in Europe \& USA and other countries like Australia, China, Israel, Libya, Bangladesh, Myanmar etc.13.33 percent in the sample area household population.

\section{Academic Qualification of the Foreign Employees}

From the sampling it was found that the educated people have gone to abroad for foreign employment. The sample foreign employees are divided into four categories namely SLC $\&$ below SLC, $10+2$, Bachelor and Master \& above. The distribution of sample foreign employees is presented in the table 2 basis of their academic qualification.

Table 2: Academic qualification of the foreign employees

\begin{tabular}{|l|c|c|}
\hline Educational Degree & Number & Percent \\
\hline SLC or Below SLC & 14 & 23.33 \\
\hline $10+2$ & 12 & 20.00 \\
\hline Bachelor & 20 & 33.33 \\
\hline Master \& Above & 14 & 23.33 \\
\hline Total & $\mathbf{6 0}$ & $\mathbf{1 0 0 . 0 0}$ \\
\hline
\end{tabular}

Source: Field Survey, 2019

Table 2, shows the academic qualification of the foreign employee's migrant people of the sample area. From the total foreign employees 23.33 percent were SLC or below SLC, 20 percent were $10+2,33.33$ percent were bachelor degree and 23.33 percent was master \& above academic qualified people are the employees in foreign country.

\section{Sources of Financing for Foreign Employment}

Migrant workers managed their financing from different sources like selling fixed assets, selfsaving, loan from relatives, friends, lender, bank etc. most of the people who went to foreign country used unofficial financing sources like loan which is shown in detail as follows: 
Table 3: Sources of financing for foreign employment

\begin{tabular}{|l|c|c|}
\hline Sources of Financing & Number & Percent \\
\hline Saving & 22 & 36.67 \\
\hline Borrowing/Loan from Relatives & 26 & 43.33 \\
\hline Loan from Lender & 5 & 8.33 \\
\hline Loan from Bank/Finance & 7 & 11.67 \\
\hline Total & $\mathbf{6 0}$ & $\mathbf{1 0 0 . 0 0}$ \\
\hline
\end{tabular}

Source: Field Survey, 2019

Table 3, expresses the sources of financing for the foreign migrant employees. From the respondent provide information at the time of questionnaire survey, it was found that the source of financing of 8.33 percent was loan from lender, 43.33 percent used the loan/ borrowing from friends/relatives, 11.67 percent used loan from bank/finance and 36.67 percent used from their household saving for the foreign migrant. Altogether 51.66 percent of them used the unofficial sources of financing which charge the high rate of interest.

\section{Time Spent in Abroad for Foreign Employees}

People who have spent more than six months in foreign countries are enumerated in this study. Among sixty sampled foreign employees, the majority of people have spent more than two years in abroad. In survey, it is found that the majority of the people who went to abroad for the first time repeated for the second and third time too. Table 4 shows the time spent in abroad by the sample area foreign employees.

Table 4: Time spent in abroad by foreign employees in the sample area people

\begin{tabular}{|l|c|c|}
\hline Duration (years) & Number & Percent \\
\hline Less than 2 Years & 4 & 6.67 \\
\hline Two Years & 12 & 20.00 \\
\hline Three Years & 10 & 16.67 \\
\hline Four Years & 10 & 16.67 \\
\hline Five Years & 8 & 13.33 \\
\hline More than Five Years & 16 & 26.67 \\
\hline Total & $\mathbf{6 0}$ & $\mathbf{1 0 0 . 0 0}$ \\
\hline
\end{tabular}

Source: Field Survey, 2019 
Table 4, shows that time spent in abroad by the foreign employees in the sample area. From the total foreign employees 6.67 percent spent less than two years, 20 percent spent two years, 16.67 percent spent three years and four years, 13.33 percent spent five years and The migrant workers who spent five years in abroad is 13.33 percent and 26.67 percent spent more than five year time abroad for the employment.

\section{Medium of Transferring Remittance}

Various sources are used for transforming remit the money from different countries. They used different official as well as individual channel like bank, money transfers and direct cash through relatives/friends as the medium of transferring remittance. Among them official channels are more popular in the sample area migrant. Table 5 expresses the remittance transferring medium of the foreign migrants.

Table 5: Medium of transferring remittance

\begin{tabular}{|l|c|c|}
\hline Medium of Sending Remittance & Number & Percent \\
\hline Money Transfer & 20 & 33.33 \\
\hline Bank & 31 & 51.67 \\
\hline Direct cash Transfer & 9 & 15.00 \\
\hline Total & $\mathbf{6 0}$ & $\mathbf{1 0 0 . 0 0}$ \\
\hline
\end{tabular}

Source: Field Survey, 2019

Table 5, express the sample area people used the medium of transferring remittance. From the total respondent 33.33 percent used money transfer, 51.67 percent used bank and 15 percent used their friend and relative for the transferring remittance in the sample area of this research.

\section{Change in Household Consumption after Receiving Remittance}

The wellbeing will be measure that sample households, whether their expenditure pattern has been changed or not after receiving the remittance. The majority of the respondents replied that the household consumption has been increased after receiving the remittances which is express from the table 6 as fallows 
Table 6: Change in household consumption after receiving remittance

\begin{tabular}{|l|c|c|c|c|}
\hline \multirow{2}{*}{$\begin{array}{l}\text { Household Con- } \\
\text { sumptions }\end{array}$} & \multicolumn{2}{|c|}{ Yes } & \multicolumn{2}{c|}{ No } \\
\cline { 2 - 5 } & Number & Percent & Number & Percent \\
\hline Food Consumption & 55 & 91.67 & 5 & 8.33 \\
\hline Health \& Education & 57 & 95.00 & 3 & 5.00 \\
\hline Clothing & 54 & 90.00 & 6 & 10.00 \\
\hline Durable Goods & 27 & 45.00 & 33 & 55.00 \\
\hline
\end{tabular}

Source: Field Survey, 2019

Table 6, express the situation of consumption pattern of the sample area household's people. Food consumption increase 91.67 percent households, health \&education facilities increase of 95 percent households, clothing consumption increase of 90 percent households and durable goods such as $\mathrm{TV}$, Mobile, computer, refrigerator etc. consumption increase 45 percent household remittance from the foreign employment. Such situation of consumption increase different goods and services shows that foreign remittance increase the wellbeing the sample area people.

\section{Investment of Transferred Remittance}

All the remittances received households did not invest that amount in productive sectors such as business, trade, project etc. It is found that a huge amount of the remittance is used for household consumption and some of the migrant workers are found saving money for future use for consumption. The investment status of sampled households shows the table 7 follows.

Table 7: Investment of transferred remittance

\begin{tabular}{|l|c|c|}
\hline Items & Number & Percent \\
\hline Remittance Invested & 38 & 63.33 \\
\hline Remittance not Invested & 22 & 36.67 \\
\hline Total & $\mathbf{6 0}$ & $\mathbf{1 0 0 . 0 0}$ \\
\hline
\end{tabular}

Source: Field Survey, 2019

The information provided by the respondent at the time of survey in sample area population shows the table 7 . From the total respondent 63.33 percent migrants have invested and 36.67 percent migrant have not investment their transferred remittance from the foreign employment. Those who had invested they saved their income and who had not invested they had not saved their money income from abroad employment. 


\section{Investment Areas of Remittance}

In questionnaire survey, seven investment areas were given as options but only three areas were chosen as remittance investment. Respondent provided information through the sample survey received remittance is basically invested in three areas like family business, land \& housing and education of children, which shows the table 8 as.

Table 8: Investment areas of remittance

\begin{tabular}{|l|c|c|}
\hline Remittance Invested Area & Number & Percent \\
\hline Family Business & 6 & 15.79 \\
\hline Land \& housing & 22 & 57.89 \\
\hline Education of Children & 10 & 26.32 \\
\hline Total & $\mathbf{3 8}$ & $\mathbf{1 0 0 . 0 0}$ \\
\hline
\end{tabular}

Source: Field Survey, 2019

Table 8, analyzes that among the remittance invested migrants, 57.89 percent migrant workers invested their saving for land \& housing and 26.32 percent migrants invested for their children's education. Both of them are non-productive sector. Only 15.79 percent foreign employees invested the remittance for family business like shop, resort, hotel etc, which create employment opportunity.

\section{Expenditure Pattern of Remittance Receiving Households before $\&$ after Receiving Remittance}

From the comparison of expenditure pattern of remittance recipient households before $\&$ after receiving remittance, it is seemed that the households whose expenditure was moderate before shifted to high and the households having low expenditure shifted to moderate after receiving remittance. It was also found that some of them had no change at all. Table 9 express the expenditure pattern oof households before and after remittance. 
Table 9: Expenditure pattern of remittance receiving households before \& after

\begin{tabular}{|l|c|c|c|c|c|c|}
\hline \multirow{2}{*}{$\begin{array}{l}\text { Expenditure } \\
\text { pattern }\end{array}$} & \multicolumn{2}{|c|}{ Increasing } & \multicolumn{2}{c|}{ No Change } & \multicolumn{2}{c|}{ Decreasing } \\
\cline { 2 - 7 } & Number & Percent & Number & Percent & Number & $\begin{array}{c}\text { Per- } \\
\text { cent }\end{array}$ \\
\hline $\begin{array}{l}\text { Household Food } \\
\text { Consumption }\end{array}$ & 31 & 51.67 & 29 & 48.33 & 0 & 0.00 \\
\hline Clothing & 20 & 33.33 & 40 & 66.67 & 0 & 0.00 \\
\hline $\begin{array}{l}\text { Education and } \\
\text { Health }\end{array}$ & 29 & 48.33 & 28 & 46.67 & 3 & 5.00 \\
\hline Durable goods & 30 & 50.00 & 26 & 43.33 & 4 & 6.67 \\
\hline Saving & 29 & 48.33 & 31 & 51.67 & 0 & 0.00 \\
\hline Others & 24 & 40.00 & 36 & 60.00 & 0 & 0.00 \\
\hline
\end{tabular}

Source: Field Survey 2019

Table 9, analyses the information provided the respondent at the time survey their expenditure pattern before and after remittance. Table shows that the 51.67 percent of RRHs' food consumption was increasing and 48.33 percent households' food consumption was found constant after receiving remittance. The majority of RRHs' expenditure on clothing was found no change i.e. 66.67 percent and remaining 33.33 percent was found increasing. The expenditure on health \& education of RRH after receiving remittance has been increasing of 48.33 percent households, has not been changed of 46.67 percent households and even has been decreasing of 5 percent households. Similarly, the expenditure on durable goods of 50 percent RRHs was found increasing, 6.67 percent decreasing and 43.33 percent was found no change. 48.33 percent of RRHs' saving was found increasing but 51.67 percent of households' saving was constant even after receiving remittance.

\section{Conclusion}

The expenditure of the households was found increasing on education, health and durable goods as well. 33.33 percent households spent high, 48.33 percent moderate and 18.34 percent households spent low on education of children and health of family after receiving remittance. It was found that the migrant worker's family has been shifted to urban area from rural area for the education of children. So, the expenditure on education was rising to high. 48.33 percent of RRHs' expenditure on education \& health was increased after receiving remittance. 41.67 percent household's expenditure on durable goods was high, 
40 percent is moderate and 18.33 percent was low. The expenditure on durable goods of 50 percent RRHs was increased. Saving of 48.33 percent households after receiving remittance has also been increasing. Majority of the households' saving was low before receiving remittance. After receiving remittance, 23.33 percent of households saving are high, 50 percent is moderate and 26.67 percent of the households have still low saving. In fact, remittance inflow increases the income level of people in the sample area. Therefore, higher amount of remittances increases the purchasing power of the people increase and their consumption also increase.

The result shows that the huge amount of remittance was not invested in productive sector. Either it was not invested and preserved for the future consumption expenditure or invested on land and housing or education of children; both of them are non-productive sectors. In the sample area, remittance has emerged as one of the major sources of income earning and they used that amount for their wellbeing. They increase their living standard through health facility, education facility and purchase of durable and comfortable goods. They invest for land and house purchase but not invest for the production as well as business. It has played a vital role in changing the lifestyle of the sample area people. But remittance was not invested in productive sectors. It was used for household consumption, which leads to increase in demand of goods. There was a need of consideration in the change of government policy so that the remittance can be channelized towards the productive sectors also, which increase investment, income employment of the local area and wellbeing of the society.

\section{References}

Acosta, P., Calderón, C., Fajnzylber, P., \& Lopez, H. (2008). What is the impact of international remittances on poverty and equality in Latin America? World Devel opment, 36(1), 89-114. https://dx.doi.org/10.1016/j.worlddev.2007.02.016 .

Bayangos, V., \& Jansen, K. (2011). Remittances and competitiveness: The case of the Philippines. World Development, 39(10), 1834-1846. https://dx.doi.org/10.1016/j. worlddev.2011.04.019

Gaudel, Y. S. (2006). Remittance income in Nepal: Need for economic development.

Journal of Nepalese Business Studies, 3(1). doi:10.3126/jnbs.v3i1.491

Hoyos, Z. (2004). Consumption and remittances in migrant households: Toward a productive use of remittances. Contemporary Economic Policy, 22(4), 555-565. 
doi: $10.1093 / \mathrm{cep} / \mathrm{byh} 042$.

Katuwal, R. (2020). Remittance and its impact on Nepalese economy. Acts Scientific Agriculture, 4 (3), 1-5. Doi: 10.31080/ASAG.2020.04.0818

Kumar, C. R. (2012). Research methodology. New Delhi: APH Publishing Corporation. Ministry of Finance (MoF). (2020). Economic Survey, 2019/20. Government of Nepal, Singh Durbar, Kathmandu, Nepal.

Neupane, N. K. (2011). An analysis impact of remittance on Nepalese economy. A M. Phil. Dissertation, Central Department of Economics, Kirtipur, T.U., Nepal. Nisar, A., \& Tufail, S. (2013). An analysis of relationship between remittances and inflation in Pakistan. Zagreb International Review of Economics \& Business, 16(2), 19-38. https://hrcak.srce.hr/file/16227

Tchantchane, P., Rodrigues, A., Fortes, G., \& Carolyne, P. (2013). An empirical study of the impact of remittance, educational expenditure and investment on growth in the Philippines. Applied Econometrics and International Development, 13(1).

Thapa, S., \& Acharya, S. (2017). Remittances and household expenditure in Nepal: Evidence from cross-section data. UN World Food Programmed, Lalitpur, Nepal. 